\title{
'Een pleister tegen tranen'
}

Voorpublicatie

In het boek Een pleister tegen tranen; Ondersteuning van kinderen

en jongeren met een ernstig zieke ouder is er ook aandacht voor

situaties waarin de ernstig zieke ouder komt te overlijden. Hoe

kunnen ouders dit slechte nieuws aan hun kinderen vertellen?

Door Tanja van

Roosmalen, Riet

Fiddelaers-Jaspers en

Machteld Lavell
Geen enkele ouder hoopt ooit in de situatie terecht te komen dat de kinderen verteld moet worden dat papa of mama dood zal gaan. Maar als die werkelijkheid er is, is het op een bepaald moment onvermijdelijk, hoe pijnlijk ook. Voor kinderen is het het fijnst om de boodschap van hun ouders te horen en niet van een ander. Indien nodig kan een professional hierbij ondersteunen, bijvoorbeeld door samen voor te bereiden hoe je dit gesprek kunt aanpakken. Bij het kiezen van het moment om dit te vertellen, is het goed om te beseffen dat de tijdsbeleving van jongere kinderen anders is dan die van volwassenen. Hoe jonger de kinderen zijn, hoe minder ze een lange tijd kunnen overzien. Als je te horen hebt gekregen dat de levensverwachting nog twee of drie maanden is, dan is dat heel kort. Maar een kleuter vraagt na een week al wanneer het nou eindelijk eens gaat gebeuren. Zoals ze de dagen tot het sinterklaasfeest of hun verjaardag aftellen, zo beleven ze ook het wachten op het moment dat hun papa of mama dood zal gaan. Dus is het van belang om het niet te lang van tevoren te vertellen maar wel lang genoeg voor hen om voorbereid te zijn en afscheid te kunnen nemen.

Het is van belang om goed op het kind af te stemmen, eerlijk te zijn en tegelijkertijd niet meer te vertellen dan ze kunnen bevatten (maar ook niet minder). Het is een kwestie van doseren en faseren. Met het ernstiger worden van de situatie pas je de woorden waarmee je kinderen informeert aan, afgestemd op de ontwikkelingsleeftijd.

\section{Eigen emoties}

Het is vrijwel onmogelijk om zo'n slecht bericht te bespreken met kinderen en daarbij de eigen emoties te verbergen. Dat hoeft ook niet. Het is natuurlijk voor kinderen niet prettig wanneer de ouder compleet overstuur is, hoewel dat door de omstandigheden weleens kan voorkomen, maar ze mogen best zien dat hun vader of moeder verdriet heeft. Zo leren ze dat verdriet bij het leven hoort, ook bij het leven van volwassenen.

Kies een plek en een goed moment om te praten. Dat kan wandelend zijn, tijdens het uitlaten van de hond, bij de ouder op schoot, met z'n allen aan de keukentafel. Het is beter om een moment overdag te kiezen, waarna er voor iedereen in het gezin nog tijd is om de boodschap te laten bezinken en een manier te vinden om de eerste emoties te uiten. Maak contact. Dat kan oogcontact zijn of een aanraking. Begin met een inleidende zin om het kind gericht te laten luisteren. 'We hebben een slecht bericht gekregen in het ziekenhuis...'

'Ik vind het heel moeilijk om je het volgende te vertellen...'

Dan volgt de boodschap, kort en krachtig zonder eromheen te draaien. Het is niet nodig een lang verhaal te vertellen. Kinderen zijn door de schok de meeste informatie meteen weer kwijt. Het gaat erom dat de boodschap overkomt en dat ze de kans krijgen deze tot zich te laten doordringen. Ze vragen zelf wel om nadere uitleg. Iedereen verwerkt de schok op zijn eigen manier. Sommigen zijn met stomheid geslagen en vluchten naar hun kamer, anderen willen dingen weten, weer anderen worden ontzettend boos of barsten in tranen uit. In veel gezinnen voelt men juist op dit moeilijke moment de verbondenheid met elkaar en kunnen de gezinsleden elkaar troosten.

Het verdient de voorkeur dat beide ouders erbij zijn als het kind wordt geïnformeerd. De zieke ouder voelt zich soms te kwetsbaar om dit aan te kunnen en kan de

Kim en Alexander hebben te horen gekregen dat Alexander een ongeneeslijke vorm van kanker heeft. Hij krijgt een levensverlengende behandeling maar er is geen hoop op beterschap. Op een mooie zaterdagochtend gaan ze met hun kinderen van 4 en 6 jaar wandelen en stoppen ze bij een prachtige grote boom. Daar lezen ze het boek 'Grote boom is ziek' voor en vertellen ze de kinderen over de ziekte van papa en zijn behandeling. Ze krijgen het woord kanker niet over hun lippen, laat staan dat hij eraan zal overlijden. In de klas van hun oudste dochter is net twee maanden ervoor de papa van een klasgenootje overleden aan kanker. 


\section{EEN PLEISTER TEGEN TRANEN}

Ondersteuning van kinderen

en jongeren met een

ernstig zieke ouder

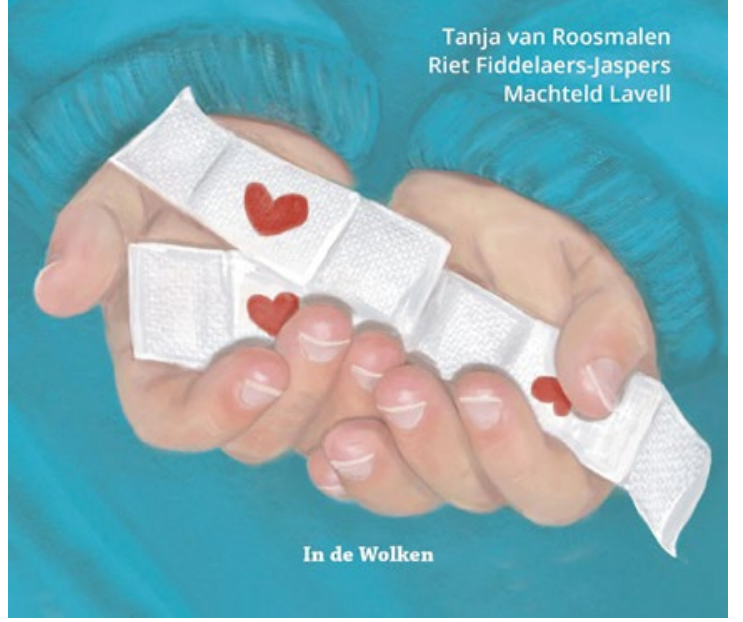

Een pleister tegen tranen

Het boek Een pleister tegen tranen geeft houvast aan professionals die te maken krijgen met een gezin waarvan een van de gezinsleden een levensbedreigende, chronische, progressieve ziekte heeft. Het boek geeft inzicht in de impact die dit op kinderen heeft en wat de veranderingen en systemische verschuivingen kunnen zijn in een gezin.

Kort na het uitbreken van de coronacrisis hebben de auteurs een speciale toevoeging voor het boek gemaakt. "De uitbraak hiervan heeft grote impact op deze gezinnen", stellen de auteurs in een toelichting. "Daarnaast zijn er gezinnen waar iedereen gezond was maar waar nu een ouder of grootouder besmet is geraakt. Daarom vonden we het nodig met een aanvulling op het boek te komen met informatie en tips. Een pleister tegen tranen; een aanvulling vanwege de impact van het coronavirus hoort onlosmakelijk bij het boek. De aanvulling is te downloaden op www.omgaan-met-verlies.nl/publicaties/downloads.

Voor meer informatie over het boek en/of het bestellen van het boek: $w w w$. in-de-wolken.nl/webshop/artikel/9789077179376/een-pleister-tegen-tranen.

neiging hebben zich terug te trekken. Voor kinderen is het echter lastig om na dit gesprek de brug te slaan in contact met de zieke ouder als die er niet bij was. Dan is er sprake van de spreekwoordelijke 'roze olifant' in de kamer, die iedereen ziet, maar waar niemand over praat, zeker niet met de zieke ouder.

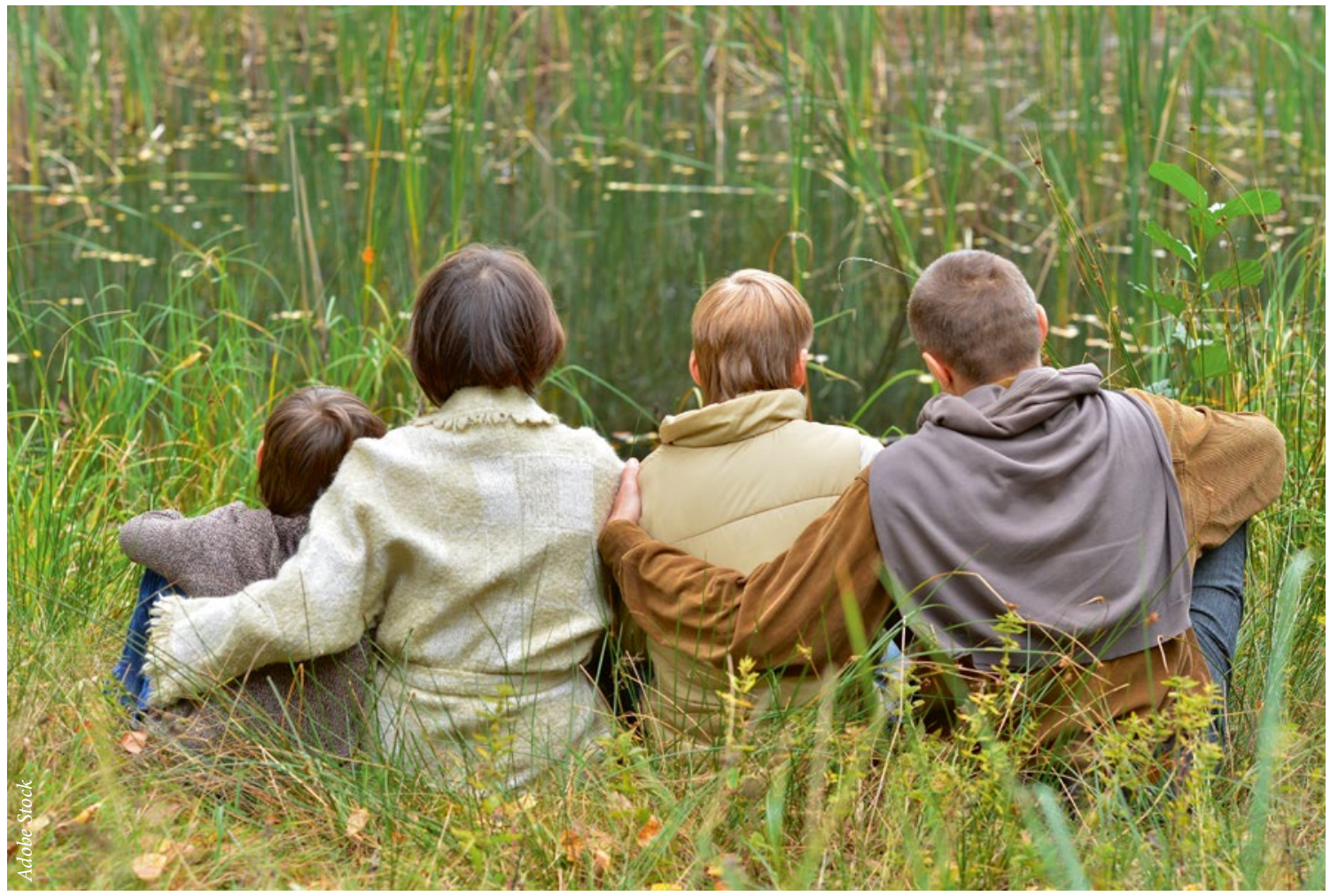


P R A K T I J K

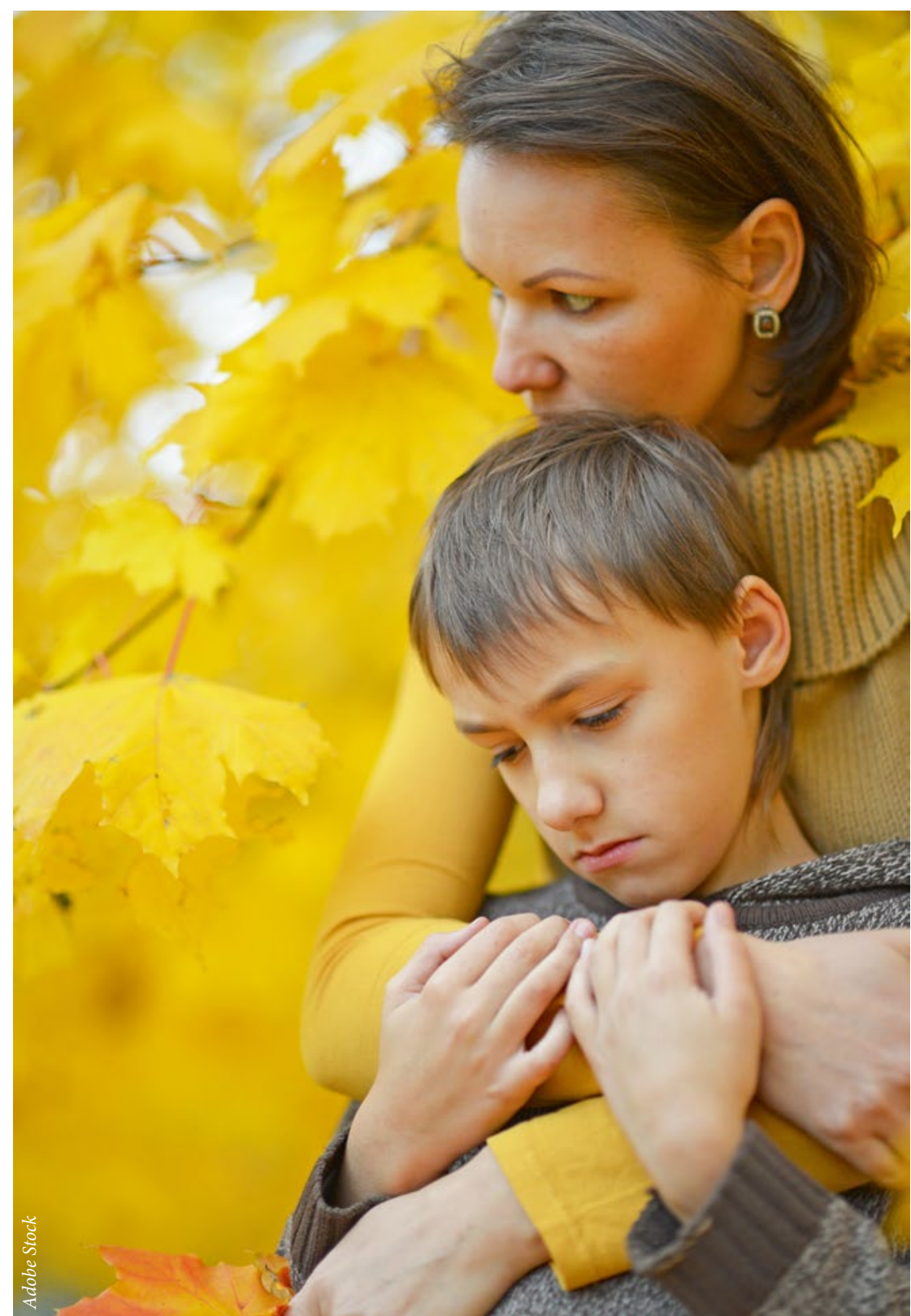

\section{Tanja van Roosmalen en}

Machteld Lavell zijn rouwen verliestherapeuten, gespecialiseerd in het begeleiden van gezinnen waar een ouder of kind ernstig ziek is. Riet Fiddelaers-Jaspers is rouw-en traumadeskundige met jarenlange expertise op dit gebied.

\section{Overlijden}

Soms vertellen ouders hun kinderen nog niet direct dat een van hen zal overlijden. Allereerst kan dat te maken hebben met het feit dat ze zelf nog niet zover zijn om die realiteit toe te laten. Dat vraagt soms tijd.

Ten tweede kan het verloop van een ziekte nog enkele jaren van achteruitgang betekenen voordat iemand overlijdt, zoals bij sommige progressieve spierziekten.
Het boek Een pleister tegen tranen wordt officieel gepresenteerd op 30 september 2020, tijdens een symposium in Culemborg. Tijdens het symposium zijn er lezingen van Riet Fiddelaers-Jaspers, longarts Sander de Hosson en journalist/auteur Rob Bruntink. Voor meer informatie: www.omgaan-met-verlies.nl/ ons-aanbod/artikel/congres16april2020/congreseen-pleister-tegen-tranen.

Als derde noemen we de situatie waarin ouders zich niet neerleggen bij de boodschap dat de ziekte ongeneeslijk is. Zij zoeken naar strohalmen om zich aan vast te kunnen klampen: een palliatieve chemotherapie, meedoen aan wetenschappelijk onderzoek naar de werkzaamheid van een nieuw medicijn, zoeken naar alternatieven buiten de reguliere geneeskunde. Alle strohalmen geven houvast en uitstel van het onvermijdelijke. Sommige ouders kunnen de woorden 'ik zal doodgaan' pas uitspreken als alle strohalmen geknakt zijn en er geen enkele strohalm meer voorhanden is. In die situaties kunnen kinderen ook in stappen meegenomen worden in het proces.

Je zou kunnen denken aan de volgende stappen:

- Papa of mama is ziek. Dat is meestal de fase dat er nog hoop is en er mogelijkheden tot behandeling zijn. Die fase is nu achter de rug of wellicht niet eens aan de orde geweest.

- Papa of mama is heel erg ziek. De dokters weten niet of ze hem of haar nog beter kunnen maken. Ook deze fase is nu gepasseerd.

- Papa of mama wordt niet meer beter. De dokters hebben heel erg hun best gedaan maar kunnen niks meer bedenken om papa of mama nog beter te maken. Vaak komen kinderen met suggesties van op internet zoeken, de beste dokter op de wereld bellen, naar een ander ziekenhuis gaan. Het is belangrijk dat ouders hierop zeggen dat die mogelijkheid er niet meer is. Mocht het kind vragen of papa of mama doodgaat, dan kun je er niet omheen draaien, en hoe moeilijk ook, dan moet ze eerlijk verteld worden dat dat inderdaad over een tijdje gaat gebeuren.

- Papa of mama wordt niet meer beter en zal doodgaan. Dit is de laatste en zwaarste stap. Het is de definitieve boodschap dat er geen uitweg meer is. Een zware boodschap om te brengen en noodzakelijk voor de kinderen. 